\title{
Learning to live on a horizontal learning curve
}

To lose one parent, Mr. Worthing, may be regarded as a misfortune, to lose both looks like carelessness.

The Importance of Being Earnest - Oscar Wilde

Women friends like to tell me that giving birth more than once can be attributed to a form of programmed amnesia. (The initial plunge can be blamed on a sense of ingrained disbelief formed by novices when listening to first hand descriptions.) Evolution seems to find it advantageous to encourage women to blur or even to purge sharp memories of the sheer horrors surrounding the event. Instead, what memories remain no more than months after the blessed event are softly backlit by all those sentimental Kodak-type moments. The agony itself is soon lost in a sepia-toned haze of forgetfulness.

Like the trauma of childbirth (though in no way its equivalent), organizing one large-scale conference ought to be sufficient for anyone capable of rational thought. Amnesia must be my only possible defence. For while it may be a misfortune to organize one conference, to deliberately persist and arrange any such subsequent events can only be scorned as sheer carelessness.

It is true that my first attempt to stage an international conference in 1998 was motivated more out of sheer ignorance and unwonted high spirits than anything else. It was sadly reminiscent of all those ancient MGM musicals where Mickey Rooney and Judy Garland decide to put on a show in an empty barn. But once having discovered exactly what happens when you place your hand on top of that particular hot stove, the wise course of action would have been to retire discreetly into the background, allowing yet another foolish tyro to take my place.

Unfortunately, after leaving the edited volume of those proceedings to the tender mercies of my publisher, the logic of the next conference insinuated itself relentlessly into my consciousness much against my own inclinations. For after dissecting the reasons for Japan's dramatic stumble in 1998, the next step logically would require an examination into the consequences of such a stumble. Would Japan actually change and embrace the sort of regime of economic reforms that so many outside observers were now quite 
strenuously urging? When I thought of the issue and some of the possible presenters who might be willing to speak at a 2000 conference, my mind subconsciously shifted gear. I suddenly told myself that given what I had learned, the next conference would be in no way as difficult, thus proving that people are condemned not to learn the most important lessons that experience has to offer.

I must admit that, as always, I was encouraged by the ongoing political structure which continues to plague Japan. In particular, the Liberal Democratic Party (LDP) of Japan seems to conspire to make each conference I organize more interesting than the last. As such, it has proved each time to be my unwitting ally. I have come to rely on the tone-deaf approach so reliably exhibited by the functionaries of that party to support my own struggling efforts. In this case I owe a particular vote of thanks to Yoshiro Mori and his curious 2000 election campaign. For my own selfish reasons I would regret to see the LDP unceremoniously booted out and replaced by a political party more interested in governing than merely holding on to government. Though to be fair, the Japanese people may have their own, quite different, preferences.

With the LDP conspiring to maintain interest in the future of Japan, I once again started to plan for the 2000 conference by inviting some of those people who initially most influenced my own thinking about the Japanese, though over the years those views have been modified by events. ${ }^{1}$ I started with the rule of thumb that what I would be interested in sitting and listening to might also intrigue a wider audience. In this particular instance I wondered what such established figures as James C. Abegglen or Ronald Dore might now think about Japan given the events of the 1990s? Had they largely reconsidered their former views or could they somehow square such events with the frameworks which they had so carefully erected over decades of research and analysis? To stir debate I looked for individuals who might present quite different views on the same subject. By heightening such contrasts, I hoped some insight would flow. I also made sure to frame the topic of the conference in the strongest possible terms in order to elicit bold, as opposed to overly cautious, responses. As always, it is left to the reader to decide to what degree I accomplished my goal.

One quick clarification which may help to explain some of the material in this volume. Readers will find that after each chapter (with the exception of that by Mikkio Wakatsuki - a lunchtime address - and James C. Abegglen - the discussant self-vaporized) there are comments by a designated discussant. All participants, both presenters and discussants, were allowed to revise their remarks subsequent to the actual conference. Naturally, the revisions were made based on those original remarks and presentations rather than on any subsequent altered versions. So there is the 
inevitable possibility that some of the discussants' comments will seem vaguely out of sync. Fortunately for the reader, I doubt that this has in fact caused any noticeable disparities in the final versions presented here.

As always, there are many people to thank and even a few who deserve tender apologies. It would be impossible to cover all who so kindly assisted this process, such as the cab driver who at 6.30 a.m., while I was trying desperately to make it to the conference hotel, was tuned to a Mozart concerto rather than the standard offerings of breakfast radio. However, there is no doubt that the conference would not have happened at all but for the efforts of Elaine Kent. Without people attending a conference, no reason for its existence remains. Elaine has the fortunate knack of convincing people, much to their own surprise, that they actually would like nothing better than to sit through a number of people talking at length about Japan. There is also the matter of funding. Bills after all have to be paid and these large events are in no way self-funding. Fortunately, Sony (Australia), under the forward-looking leadership of Haruyuki Machida, kindly stepped in to assist with some of those pesky bills. Jenny Geddes of Sony (Australia) also proved to be an ideal person to turn to for any assistance in these matters, never put off by a momentary difficulty. Nobutake Odano, Consul-General of Japan, was kind enough to take an interest in our efforts and, by extending his hospitality, provided a memorable ending to the conference itself. Meanwhile, Edward Elgar continues to be a perfect gentleman, perhaps illustrating the difference between a publisher and a media mogul. Nor could I ask more from his sometime changing but always diligent publishing crew.

Lastly I owe a series of apologies to my family who found me to be absent without leave for so many months in both the lead up to and the aftermath of the conference. My two six-year-old girls continue to be mystified by what I do for so much of my time, almost as mystified as I am myself.

Craig Freedman

December 2000

\section{NOTE}

1. When asked why he seemed so often to change his mind, it is reported that Keynes replied, 'When the facts change, I change my mind. What do you do?' I hope that I have over the years managed to escape the worst pitfalls of dogmatism. 